\title{
TELJESÍTMÉNYÉRTÉKELÉS A PROFESSZIONÁLIS KOSÁRLABDÁBAN
}

A professzionális sportban, mint minden iparágban, a teljesítmény mérése kulcsfontosságú. Az alkalmazott módszereknek mérniük kell a csapat teljesítményét, azt össze kell hasonlítani az ellenfelekével, meg kell határozni azokat a faktorokat, standardokat, amelyek szükségesek a sikeres szerepléshez. A módszereknek mérniük kell a sportolók egyéni teljesítményét, az egyéni hozzájárulás mértékét a csapat eredményéhez és információkat kell nyújtaniuk a piac számára, hiszen a játékosok nagyrészt korábbi teljesítményük alapján kerülnek értékelésre. A teljesítményértékelés egyben a játékosok ösztönzésének fontos forrása is, ezért a hatékony menedzselés szempontjából olyan módszer kidolgozása szükséges, amely a szervezet céljait és az egyéni célokat sikeresen koordinálja.

Habár a statisztikai módszerek fejlődésével egyre inkább leírható a komplex környezet, a korlátozott kognitív képességek miatt ezek mindig le fogják egyszerúsíteni a bonyolultabb problémákat. Drucker (1991) szerint a hatékony döntéshozó mindig feltételezi, hogy az aktuálisan alkalmazott mérési módszer rossz, és ezért kísérletet tesz a fogalmak tisztázására és a környezet újrastruktúrálására. A tanulmány célja szerint a szerző által kidolgozott értékelő, ösztönző és informáló rendszer ezzel az újraértékeléssel segítheti elő a szakértők hatékony döntéshozatalát.

A kosárlabdában alkalmazott statisztikai rendszer amellett, hogy a modern sport jellegzetessége miatt kiszolgálja a média, a néző érdeklődését, betölti a teljesítményértékelés funkcióját is, s ezzel információt nyújt a sportmenedzseri döntésekhez. E döntések megértéséhez, elemzéséhez szükséges, hogy a módszert szembesítsük azokkal a követelményekkel, melyeket a modern szervezetelméletek állítanak a teljesítményértékelő és ösztönző rendszerekkel szemben. A feltételezett hibák azonosítása módot ad arra, hogy ajánlásokat fogalmazzunk meg a módszer javítására és alkalmas a rendszer átdolgozására.

A hatékony teljesítményértékelő és ösztönzô rendszer kialakításának a szervezetrôl való feltételezéssel kell kezdődnie. Ebból a szempontból a professzionális sportban el kell fogadni a közgazdasági szemléletet, ami szerint az egyének önérdekkövetô döntéseket hoznak, s csak akkor kötnek megállapodásokat, ha azoktól kölcsönös előnyöket várnak. A szervezeti viselkedést így a hatékony szerződésekre adott önérdekkövető válaszok eredményének tekinthetjük.

Az emberierôforrás-gazdálkodás szempontjából a professzionális kosárlabdát a másodlagos szektorhoz sorolhatjuk. Ennek oka, hogy a játékos és csapat között rövid távú foglalkoztatási szerződések jellemzôk, előreléptetésrôl nem beszélhetünk, s a béreket szinte teljes egészében a piaci erók határozzák meg. ${ }^{1}$ Mivel a játékosok munkaszerzódése a legpontosabb fogalmazás ellenére is hiányos, illetve a megkövetelhető teljesítmény homályos, ezért a menedzsment versenyelőnyre a rövid távú érdekek meghaladásán keresztül, a csapat szintú célok iránti elkötelezettség és a társakkal való kooperatív magatartás kialakításával tehet szert.

A professzionális kosárlabda csapat teljesítménye 5, cserékkel együtt 10-12 játékos olyan koordinált cselekvését jelenti, melynek célja az ellenfél legyőzése. Feltételezve, hogy a játékosok önérdekkövető döntéseket hoznak, a menedzsmentnek (ami megegyezhet az edzői pozícióval is), olyan ösztönző rendszert kell kialakítania, amely az egyéni célokat összhangba hozza a csapat céljával. A ma használatos statisztikai eljárások legnagyobb hibája az, hogy semmilyen jele sincs az egyéni mutatókban annak, hogy a csapat az adott mérkőzést megnyerte vagy elvesztette, pedig a kosárlabdában egyedül a csapat eredményessége számít! (1.táblázat)

Milgrom (2004: 437.old.) 


\section{1. táblázat}

Mérközéseredmény és az IBM-mutató összehasonlitása (Sterbenz, 2006). ${ }^{2}$

\begin{tabular}{|l|c|c|}
\hline \multicolumn{3}{|c|}{ NB I A Csoport 2005-06 Alapszakasz } \\
\hline Nôi Mérkôzések & Eredmény & IBM \\
\hline Sopron - Pécs & $66-64$ & $84-101$ \\
\hline BSE - Pécs & $62-68$ & $87-80$ \\
\hline & & \\
\hline Férfi Mérkôzések & Eredmény & IBM \\
\hline Kecskemét - Körmend & $86-90$ & $126-97$ \\
\hline ZTE - Pécs & $72-76$ & $121-95$ \\
\hline Albacomp - Dombóvár & $74-81$ & $108-100$ \\
\hline Szolnok - Sopron & $80-78$ & $108-112$ \\
\hline
\end{tabular}

Statisztikai elemzésre a döntéshozók korlátozott racionalitása miatt van szükség. A Herbert Simon-féle elmélet szerint a korlátozott kognitív képességek és a környezet bonyolult struktúrája az oka annak, hogy a döntéshozó legjobb szándéka ellenére sem képes tökéletesen racionális viselkedésre. Mivel a kosárlabda olyan komplex és gyors játék, amit még a legalaposabb elemzés sem alkalmas tökéletesen leírni, törvényszerú, hogy kialakultak azok a módok, amelyek legalább megközelítőleg képesek a teljesítményt bemutatni. A statisztikai elemzés sohasem képes mérni a játékos teljes hozzájárulását a csapat teljesítményéhez, de a szisztematikus torzítások kiküszöbölhetőek.

\section{A jelenlegi statisztikai rendszer}

Kosárlabdában világszerte hasonló eljárás alapján készítik a mérkőzések statisztikai elemzését. Ebben megkísérlik rögzíteni valamennyi lényeges olyan eseményt, amely a mérkőzés végeredményét befolyásolja, s ezt egyenként, illetve csapat összesítésben értékelik. A szakemberek konszenzusa alapján a következő események feljegyzésére kerül sor:

- dobások (mezőny- és büntető; sikeres és összes),

- lepattanó labdák (védő és támadó palánk alatt),

- assziszt átadások (,gólpassz”),

- személyi hibák (kiharcolt, illetve elkövetett),

- eladott és szerzett labdák,

- dobásszerelések („,blokk”),

- játékidő.

Ezek az események a mérkôzés közben jól nyomon követhetók, és standard értékelólapok vagy szoftverek segítségével rögzíthetốk. A szakemberek a mutatók öszszesítésére kidolgoztak egy olyan mérőszámot, amely a fenti faktorokat összesíti, s így az egyéni teljesítményt értékeli, összehasonlíthatóvá teszi. Ez a (Magyarországon IBM-mutatónak nevezett) szám, a következő képlettel kapható meg:

IBM = Dobott Pont + Lepattanó Labda + Assziszt + Szerzett Labda + Blokk - Eladott Labda - Rossz Dobások

Az IBM-mutató az egyes játékeseményeket pozitív vagy negatív elójellel, de súlyozás nélkül számítja, s ezzel torzítja a játék struktúrájának leírását. A szakemberek ezen gyakran úgy próbáltak segíteni, hogy empirikus vagy spekulatív úton az egyes eseményeknek más és más súlyt adtak, s így próbálták meg azok jelentőségét hangsúlyozni. (2. táblázat)

\section{A módszer legfontosabb hibái:}

- Az egyéni és csapat célok nincsenek összhangban, az egyén értékelése független a csapat eredményétôl, illetve a csapat statisztikai összmutatója (IBM-mutató) nincs összhangban a csapat eredményével.

- Az alkalmazott mutatók az abszolút teljesítményt mérik, a hatékonyság elemzése nem szerepel a rendszerben. A mutatók abszolút értéke nagymértékben függ a mérkőzések tempójától, a támadások számától.

- A játékot a statisztika a korlátozott racionalitás elmélete szerint leegyszerúsíti, ezzel fontos játékelemeket hagy ki az elemzésból.

- A mért játékelemek súlyozás vagy empirikus adatok feldolgozása nélküli becslés alapján kerülnek a statisztikai mutatókba, ezért az értékeló függvény torzít.

- A teljesítmény szempontjából döntô jelentôségú együttmúködést nem értékeli a statisztika, ezzel lehetôséget ad az opportunista viselkedésre (önző játék).

A kosárlabda játékstruktúrájának lényege, hogy a támadás és védekezés a teljesítmény szempontjából egyenló súlyú, s a mérkőzést a dobott és kapott pontok különbsége dönti el. A jelenlegi módszer ezzel szemben a támadó játékelemeket hangsúlyozza, amivel a játékosokat

A 2005-06-os élvonalbeli magyar bajnokság alapszakaszában (A csoport) 5 nói és 15 férfi mérkőzésen fordult elő az a helyzet, hogy a mérkôzést nem az csapat nyerte, amelyik a hivatalos statisztikai lap alapján több IBM-pontot szerzett.

A mutató egyes változatai számolnak az elkövetett, illetve kiharcolt személyi hibával is

Rövidítések jelentése: DP - dobott pont; Asz - assziszt labda; TL - támadó lepattanó; VL - védô lepattanó; SzL - szerzett labda; BL - blokkolt labda; RD - rossz mezónydobás; RB - rossz büntetôdobás; EL - eladott labda 


\section{2. táblázat}

Az egyes játékosesemények statisztikái (Oliver, 2004 és Németh, 1981a alapján)

\begin{tabular}{|c|c|c|c|c|c|c|c|c|c|c|c|}
\hline & Manley & Hoopstat & Steele & Heeren & Bellotti & Claerbaut & Mays & Schaller & Hollinger & Berri & Németh \\
\hline DP & 1 & 1 & 1 & 1 & 1 & 1 & 1 & 1 & 1 & 1 & 1 \\
\hline Asz & 1.00 & 1.39 & 1.25 & 1.00 & 1.08 & 0.63 & 0.98 & 0.90 & 0.79 & 0.92 & 1.00 \\
\hline TL & 1.00 & 1.18 & 1.00 & 1.00 & 0.92 & 0.63 & 0.71 & 0.75 & 0.85 & 3.82 & 1.00 \\
\hline VL & 1.00 & 0.69 & 1.00 & 1.00 & 0.92 & 0.63 & 0.71 & 0.75 & 0.35 & 1.71 & 1.00 \\
\hline SzL & 1.00 & 1.39 & 1.25 & 1.00 & 0.92 & 0.63 & 1.09 & 1.80 & 1.20 & 2.44 & 2.00 \\
\hline BL & 1.00 & 1.94 & 1.00 & 1.00 & 0.92 & 0.63 & 0.87 & 1.10 & 0.85 & 0.86 & - \\
\hline RD & -1.00 & -0.83 & -1.00 & -1.00 & -0.92 & -0.63 & -0.71 & -1.00 & -0.85 & -1.38 & 0.00 \\
\hline RB & -1.00 & 0.00 & -0.50 & -1.00 & -0.92 & -0.24 & -0.55 & -0.90 & -0.45 & -0.79 & 0.00 \\
\hline EL & -1.00 & -1.11 & -1.25 & -1.00 & -0.92 & -0.63 & -1.09 & -1.80 & -1.20 & -2.77 & -2.00 \\
\hline
\end{tabular}

pontszerzésre ösztönzi, de elhanyagolja a csapatjáték más aspektusait (labda nélküli mozgás, elzárások). Védekezésben a rendszer csak a nyilvánvaló, jól látható eseményeket díjazza (lepattanó, szerzett labda, dobásszerelés), s nem értékeli az ellenfél hibáit kikényszerítô cselekedeteket, ezzel torzítja a teljesítményt.

\section{A javított statisztikai rendszer szükséges tulajdonságai}

A kosárlabda struktúráját az elemzésnek úgy kell leírnia, hogy elkerülje a korlátozott racionalitás miatt alkalmazott heurisztikus döntésekból fakadó csapdákat ${ }^{5}$, és megközelítse az objektív teljesítményértékelést. Természetesen a statisztikai módszerek a teljes objektivitást sohasem lesznek képesek elérni, de a menedzseri döntésekhez szükséges információknak a mainál nagyobb megbízhatóságot kellene tanúsítaniuk.

A javított módszerben az egyéni teljesítményértékelést összhangba kell hozni a csapat céljával, mivel az előbbi hangsúlyozása nem ösztönzi a játékosok közötti kooperációt. Elfogadva azt a játékelméleti megállapítást, hogy belső, logikai ellentmondás lehetetlenné teszi ideális ösztönzố rendszer kialakítását (Miller, 2002), olyan eljárás kidolgozása szükséges, amely rábírja a szervezet tagjait az együttmúködő magatartásformára.

\section{A hatékonyság mérése}

A professzionális kosárlabdában egy csapat célja lehet a bajnoki cím elhódítása, az adott mérkôzés megnyerése vagy, még rövidebb távon, egy támadás sikeres befejezése. Ezek a célok, bár természetesen összefüggenek, nem teljesen fedik le egymást, s ezért elemzésünkhöz ki kell választani azt az egységet, melynek tükrében az ésszerüséget, a hatékonyságot értékelni tudjuk. Mivel a versenysportban a mérkôzés az az egység, amelynek megnyerésével juthat el a csapat hoszszabb távú céljaihoz, kézenfekvő, hogy ezt válasszuk az elemzés alapjául.

Kosárlabdában a csapatok felváltva jutnak a labdabirtoklásához, ami azt jelenti, hogy az ellenfeleknek azonos számú (maximum egy eltéréssel) támadás áll rendelkezésre. A gyôzelmet az szerzi meg, aki támadásaiból több pontot szerez, mint ellenfele a sajátjaiból. A támadásokból szerzett pont önmagában, abszolút mutatóként nem segíti a célok elérésének elemzését, hiszen csak az ellenfél mutatóival összehasonlítva jelent valamit. A dobott, illetve kapott pontok összehasonlítása más mérkőzésekkel, standardokkal sem értelmezhető, (bármennyire hajlamos erre minden szereplő), hiszen a támadások száma, a mérkőzés tempója fontos meghatározója az elérhetô pontoknak.

A támadás és védekezés hatékonyságának mérésére évtizedek óta kidolgoztak egyszerú módszereket, ezek azonban szakmai berkekben sem terjedtek el. ${ }^{6}$ Ezek szerint egy csapat támadásának hatékonyságát pontosan mutatja az a hányados, amit a dobott pontok a labdabirtoklások számával való osztása után kapunk:

\section{Támadó Érték = Dobott pont/Labdabirtoklás}

Egy mérkőzésen a labdabirtoklás számát a hagyományos statisztikai lap nem jegyzi, de az összesített adatokból könnyen kiszámítható, illetve becsülhetô. Kosárlabdában a labdabirtoklások mezónydobással, büntetődobással vagy eladott labdával végződhetnek, s ezekból csak a büntetődobások száma nem számolható

\footnotetext{
Sterbenz (2003)
}

Smith (1981) 
automatikusan támadásnak. Mivel a dobott kosár után kapott ráadás egy büntetô nem jelent új támadást, a három büntetô pedig egy labdabirtoklás befejezéseként számolandó, becslésként a büntetôdobások számának felét, vagy pontosabban 44 százalékát kell használni.?

\section{Támadásszám $=$ Mezónydobás $+($ Büntetódobás $x$ 0.44) + Eladott labda - Támadó lepattanó}

A támadó lepattanók a képletben levonásra kerülnek, hiszen új labdabirtoklás csak akkor kezdődik, amikor az ellenfél birtokába kerül a labda (ez biztosítja, hogy a két csapatnak egyenlő számú támadása legyen mérkőzésenként).

Egy csapat megnyeri az adott mérkôzést, ha Támadó Értéke meghaladja saját Védő Értékét, ami megegyezik az ellenfél Támadó Értékével. Az edző számára a két mutató jó eszközt jelent a támadás és a védekezés értékeléséhez, de a legjobban az segítheti a racionális stratégia kialakítását, ha megtalálja azokat a tényezôket, amelyek a két érték maximalizálásához, illetve minimalizálásához vezetnek. A jelenleg ismert kutatások négy olyan kritikus faktort azonosítottak, amelyek szignifikánsan hozzájárulnak a hatékonyság növeléséhez:

1. mezónydobó százalék,

2. büntetó dobások száma,

3. mezónydobások száma,

4. támadó lepattanók száma.

A kritikus tényezók megértését segíti az, ha tudjuk, a professzionális kosárlabdában a Támadó Érték 1 körül ingadozik, vagyis támadásonként a csapatok átlagosan 1 pontot érnek el. (3. táblázat)

\section{3. táblázat}

Támadó Érték - NBA Átlag (Hollinger, 2005)

\begin{tabular}{|c|c|}
\hline Év & TÉ \\
\hline $1995-96$ & 1,054 \\
\hline $1996-97$ & 1,044 \\
\hline $1997-98$ & 1,009 \\
\hline $1998-99$ & 1,000 \\
\hline $1999-00$ & 1,019 \\
\hline $2000-2001$ & 1,009 \\
\hline $2001-2002$ & 1,023 \\
\hline $2002-2003$ & 1,014 \\
\hline $2003-2004$ & 1,008 \\
\hline $2004-2005$ & 1,031 \\
\hline
\end{tabular}

${ }^{7}$ Hollinger (2005)

8 Oliver (2004)

\section{A ,pontosztás”-módszer}

A pontosztáson alapuló módszer alapgondolata, hogy az értékelő rendszernek „költségvetés betartónak” kell lennie, vagyis azon a teljesítményen kell alapulnia, amit a játékosok összesen elértek. Ez a támadásokban a dobott pontok összegével, védekezésben pedig, negatív előjellel, a kapott pontokkal egyezik meg. E kettó különbsége adja a mérkőzésen a két csapat közti eltérést, ami jellemzi a csapat teljesítményét. Például ha a csapat 90 pontot dob és 70 pontot kap, akkor a támadások értékelésében +90 pont szétosztását kell megtenni, míg a védekezésben -70 pont kerül elosztásra. A csapat összmutatója így megegyezik a +20 pontos különbséggel, ami reálisan jellemzi a csapat teljesítményét. A pontosztás módszer elfogadja, hogy csak az eredmények figyelhetóek meg, de így is lehetőséget ad a finomításra.

Az „egyszerú pontosztás” a játékosok teljesítményét két tényezố alapján értékeli:

- szerzett pontok,

- kapott pontok.

A ,pontosztás” a korábban elemzett módszerektól eltéróen nem a könnyen megfigyelhetô játékelemeket rögzíti, hanem a mindenkori pontszerzés körülményeit elemezve, az együttmúködést hangsúlyozva osztja el a megszerzett vagy kapott pontokat. Abban az esetben, ha a módszert valódi szakember alkalmazza, a rendszer kikerüli a hozzáférhetôségi heurisztikából fakadó csapdákat, s reálisabb képet ad a csapat, illetve a játékosok teljesítményéról. (4. táblázat)

A kosárlabdában egy labdabirtoklás $0,1,2$ vagy 3 ponttal zárulhat (extrém esetekben 4 pontot is elérhet a támadó csapat), ezért a pontosztásnak is az aktuálisan megszerzett pontokat kell felosztania a pályán tartózkodó játékosok között. A hagyományos rendszer hibája, hogy a pontot dobó játékos mellett kizárólag az assisztlabdát adó játékost jutalmazza, azt viszont úgy, hogy teljesítményében +1 pontot kap. Ez a módszer megsérti a „költségvetés-betartás” elvét, hiszen többet oszt szét a játékosok között, mint amit „,megtermeltek”.

A pontosztó módszer azzal, hogy a megszerzett pontokat osztja szét a játékosok között, kiküszöböli a hagyományos rendszerek torzító hatását. A módszer megfelel annak a követelménynek is, hogy ösztönözze az együttmúködést, hiszen a ,pontosztás” nem csak a kosár előtti átadást jutalmazza, hanem minden olyan játékelemet, amely hozzájárult a megszerzett pontokhoz. Így a jó elzárást adó játékos vagy a létszámfölényes helyzetben labda nélküli, de fontos szerepet betöltố társ is kaphat az elosztható pontokból. 


\section{4. táblázat \\ Sopron - Pécs ,egyszerü pontosztás” \\ (Sterbenz, 2006)}

\section{MKB - Euroleasing Sopron}

\begin{tabular}{|l|c|c|c|c|}
\hline Játékos & Szerzett Pont & Kapott Pont & Pontosztás Érték & IBM \\
\hline Teasley N. & 14 & 10 & 4 & 16 \\
\hline Károlyi A. & 10 & 6 & 4 & 9 \\
\hline Csernyi R. & 11 & 11 & -7 & 19 \\
\hline Honti K. & 5 & 12 & -2 & 5 \\
\hline Horváth Zsu. & 9 & 11 & 3 & 15 \\
\hline Eördög E. & 9 & 6 & 0 & $\mathbf{2}$ \\
\hline Matovic I. & 8 & 8 & $\mathbf{6 4}$ & $\mathbf{8 4}$ \\
\hline Összesen & $\mathbf{6 6}$ & & & \\
\hline
\end{tabular}

\section{MIZO Pécs}

\begin{tabular}{|l|c|c|c|c|}
\hline Játékos & Szerzett Pont & Kapott Pont & Pontosztás Érték & IBM \\
\hline Béres T. & 7 & 7 & 0 & 19 \\
\hline Johnson V. & 8 & 9 & -1 & 14 \\
\hline Iványi D. & 20 & 8 & 12 & 21 \\
\hline Dapo A. & 9 & 12 & -3 & 18 \\
\hline Branzova A. & 14 & 10 & 4 & 19 \\
\hline Fegyverneki Zs. & 1 & 3 & -2 & 0 \\
\hline Johns P. & 4 & 14 & -10 & 6 \\
\hline Bujdosó N. & 1 & 3 & -2 & 4 \\
\hline Összesen & $\mathbf{6 4}$ & $\mathbf{6 6}$ & $\mathbf{- 2}$ & $\mathbf{1 0 1}$ \\
\hline
\end{tabular}

A gyakorlatban célszerú, hogy a teljesítmény értékelését a szakmai munka felelőse végezze. Ennek oka, hogy ő az, aki tisztában van a játékosok szerepköreivel, aktuális feladataival, s meg tudja ítélni a laikus számára érthetetlen, bonyolult szituációkat is. Amenynyiben az elemzés videofelvételról történik, a szakemberek számára a játékhelyzetek elemzése nem jelent problémát, s az elemzés költségeit meghaladják a várható hasznok.

A ,pontosztás”-módszere összekapcsolja a támadás és védekezés értékelését. A játékban gyakran előfordul, hogy eladott labda után a csapat képtelen rendezett védelembe szervezódni, s az ellenfél könnyú pontokhoz jut. Ebben az esetben a kapott pontok felelőse a támadásban hibázó játékos, hiszen annak következménye, hogy a védekezés nem tudott sikert elérni.

A ,pontosztás” a támadást és védekezést a játék struktúrájának megfelelôen egyenrangúan kezeli. Ez a fontos értékelési szempont egyetlen korábbi módszer alapján nem volt követhető, pedig a reális teljesítmény e nélkül nem értelmezhető! Mint a táblázatból látható magas IBM-értekkel és Szerzett Ponttal rendelkező játékosok teljesítményértéke a Kapott Pontok miatt negatív is lehet.

\section{A ,kibóvített pontosztás”}

Mivel a kosárlabdában professzionális szinten a labdabirtoklások értéke megközelítóleg 1 , ez az érték felhasználható az elhibázott támadások, illetve a sikertelen védekezések értékelésére. Így a korábban bemutatott Szerzett Pont és Kapott Pont mutató kiegészül a Jó Védekezés és a Támadó Hiba mutatójával. Ez a négy tényező együttesen felöleli a kosárlabdacsapat összteljesítményét és reális képet ad a mérkőzés egészéról.

Játékos nettó teljesítménye $=S z P+J V-K P-T H$

A kibővített pontosztás módszerét a magyar női kosárlabda válogatott mérkőzésén keresztül ismertetem. En- 


\section{5. táblázat}

Magyarország - Finnország (2005) „kibővített pontosztás”

(Sterbenz, 2006)

\begin{tabular}{|l|c|c|c|c|c|c|c|}
\hline Név & IBM & Pontosztás & SzP & KP & TH & JV & Nettó Érték \\
\hline Fegyverneki & 12 & 5 & 8 & 3 & 2 & 4 & 7 \\
\hline Englert & 20 & 5 & 10 & 5 & 1 & 5 & 9 \\
\hline Czukor & 0 & 0 & 0 & 0 & 1 & 2 & 1 \\
\hline Ujhelyi & 13 & 3 & 7 & 4 & 1 & 7 & 9 \\
\hline Török & 4 & 0 & 2 & 2 & 1 & 0 & -1 \\
\hline Horváth Zsuzsa & -1 & 0 & 2 & 2 & 5 & 2 & -3 \\
\hline Cserny & 21 & 5 & 21 & 16 & 6 & 7 & 6 \\
\hline Papp & 9 & 2 & 5 & 3 & 2 & 2 & 2 \\
\hline Hagara & 6 & 0 & 6 & 6 & 5 & 7 & 2 \\
\hline Horváth Zsófia & -2 & -1 & 0 & 1 & 1 & 1 & -1 \\
\hline Szakács & 2 & 1 & 1 & 0 & 1 & 1 & 1 \\
\hline Károlyi & 13 & 10 & 11 & 1 & 4 & 5 & 11 \\
\hline Összesen & $\mathbf{9 7}$ & $\mathbf{3 0}$ & $\mathbf{7 3}$ & $\mathbf{4 3}$ & $\mathbf{3 0}$ & $\mathbf{4 3}$ & 43 \\
\hline
\end{tabular}

nek oka, hogy a korrekt elemzéshez ismerni kell a csapat támadó és védô stratégiáját, s az értekezés szerzóje ezen a mérkőzéseken volt a fenti feladatok kidolgozója. Meg kell jegyezni, hogy a mérkőzések a módszer bemutatására alkalmasak, de a professzionális játékosokról feltételezett önérdekkövetố magatartás válogatott mérkőzések esetén nem helyes (Sterbenz, 2005). (5. táblázat)

A táblázatból látható a pontosztás módszere szerinti értékelés és a hagyományos IBM-mutató közötti eltérés. A pontosztás a mérkôzés +30 pontos értékét adja a csapat összteljesítményének, a semmitmondó 97 IBMpont helyett. Az egyéni teljesítmények jobb értékelését a kapott pontok „elég jól” árnyalják, de a finomított módszer szerinti két új mutató teszi teljessé azt. A Támadó Hibák és Jó Védekezések eltérése a mérkőzésen kialakult nagy különbségnek köszönhetô, ezek szoros végeredmény esetén közel azonosak. A kapott pontok és a jó védekezések egyezósége csak a véletlennek köszönhetô, átlagosnak számító mérkôzésen a kapott pontok a jó védekezés dupláját teszik ki.

A mérkőzés aktuális támadó és védő értékét felhasználva igen jól kiszámítható, hogy milyen hozzáadott értéke volt a jó védekezéseknek, illetve milyen hátrányt szenvedett a csapat a támadásokban elkövetett hibák miatt. A fenti találkozón az átlagosnak tekintett 1-tôl mindkét csapat támadó értéke jelentôsen eltért: 1,14 , illetve 0,67 volt.

\section{Összefoglalás}

A kosárlabda régóta tárgya a döntéselméleti kutatásoknak, s a tudományos eredmények gyakran hoztak a szakemberek vélekedéseivel ellentétes megállapításokat. Az egyes játékelemek határtermékének megállapítása (Berri, 1999 b), az elsüllyedt költségek elemzése (Staw - Hoang, 1995, illetve Camerer - Weber, 1999), vagy a reprezentativitási heurisztikából fakadó csapdák elkerülése (Gilovich - Vallone - Tversky, 1985), mind értékes hozzájárulást jelentettek a racionális játékstratégia és a hatékony menedzsment kidolgozásához.

A cikk szerzője által kidolgozott ,pontosztásos”módszer lehetôvé teszi, hogy a menedzsment az önérdeküket követô játékosok magatartását organikus problémává alakítsa át, s ezzel elérje, hogy azok lépjenek túl rövid távú érdekeiken. Az eljárás szervezetelméleti szempontból megalapozott, s így számítógépes rendszerrel való továbbfejlesztése az elemzés költségeit nagyban csökkentené, a feldolgozhatóság pontosságát növelné.

A statisztikai módszerek javítása a sportmenedzseri döntések sajátossága miatt nem jelenthet hosszú távú versenyelőnyt, az ellenfélnél jobb döntések meghozatalához mindig szükség lesz intuícióra is. Ennek ellenére a professzionális kosárlabda világában feltételezhetô, hogy a javított módszer alkalmazásával a statisztika megszúnhet a vesztesek vigaszaként szolgálni. 


\section{Felhasznált irodalom}

1. Albert, Jim - Bennett, JAy (2001): Curve Ball: Baseball, Statistics, and the Role of Chance in the Game Springer - Verlag, New York

2. Bellotті, Вов (2003): The Magic Number: Points Created in: The Total Basketball: The Ultimate Basketball Encyclopedia (Shouler, Ken - Ryan, Bob - Smith, Sam - Koppett, Leonard - Bellotti, Bob) Sport Media Publishing, Toronto

3. Berri, David J. - Brook, Stacey L. (1999): Trading Players in the National Basketball Association: For Better or Worse in: Sport Economics (Current Research) Praeger; Westport, Connecticut

4. Berri, DAVID J. (1999): Who is 'Most Valuable'? Measuring the Player's Production of Wins in the National Basketball Association, Managerial and Decision Economics, 20.: 411-427. p.

5. Camerer, Colin F. - Weber, Roberto A. (1999): The econometrics and behavioral economics of escalation of commitment: a re-examination of Staw and Hoang's NBA data, Journal of Economic Behavior \& Organization Vol. 39 59-82. p.

6. Drucker, Peter F. (1991): A hatékony vezetó, Park, Bp.

7. Friedman, Arthur - Cohen, Joel (1978): The World of Sports Statistics: How the Fans and Professionals Record, Compile and Use Information Atheneum, New York

8. Gigerenzer, Gerd - Reinhard Selten (ed.)(2002): Bounded Rationality: The adaptive toolbox MIT, Cambridge - London

9. Gilovich, Thomas - Vallone, Robert - Tversky, Amos (1985): The Hot Hand in Basketball: On the Misperception of Random Sequences, Cognitive Psychology, 17, 295-314. p.

10. Hollinger, John (2005): Pro Basketball Forecast Potomac Books, Washington

11. Kalb, Elliott (2003): Who's Better, Who's Best in Basketball, Contemporary Books, New York 410 p.

12. KREPS, (2005): Játékelmélet és közgazdasági modellezés Nemzeti tankönyvkiadó, Budapest
13. Linton, Arthur R. (1998): How to Grade and Rank Every Basketballer in History, Upublish, h. n. 94 p.

14. Milgrom, Paul - Roberts, John (2005): Közgazdaságtan, szervezetelmélet és vállalatirányítás Nemzeti Tankönyvkiadó, Budapest

15. Miller, Gary J. (2002): Menedzserdilemmák: A hierarchia politikai gazdaságtana Aula, Budapest

16. NÉMETH LÁszLó (1981a): Kosárlabda mérkózések megfigyelése, értékelése, konzekvenciái az edzésmunkában, TF Doktori értekezés, Budapest

17. NÉMETH LÁSZLó (1981b): A mérkózésteljesítmény statisztikai értékelése, A Testnevelési Fôiskola Közleményei 2. sz. 231-244. old.

18. Oliver, Dean (2004): Basketball on Paper: Rules and Tools for Performance Analysis Brassey's, Washington

19. Smith, Dean (1981): Basketball: Multiple Offense and Defense, Prentice Hall, New Jersey

20. Staw, Barry - HoAng, Ha (1995): Sunk Cost in the NBA: Why Draft Order Affects Playing Time and Survival in Professional Basketball, Administrative Science Quarterly, 40. 474-494

21. Sterbenz Tamás (2003): Sportmenedzseri döntések, Vezetéstudomány 6. sz. 23-30. old.

22. STERBENZ TAMÁs (2005): Válogatott menedzsmentproblémák: Stratégia a magyar nói kosárlabda válogatottnál, Vezetéstudomány, 7-8. sz. 66-69. old.

23. Swalgin, Ken (1994): The Basketball Evaluation System: A Scientific Approach to Player Evaluation, in.: Coaching Basketball (Krause, Jerry szerk..) Masters Press, Indianapolis, 40-43. p.

24. Tversky, Amos - Gilovich, Thomas (1985): The Cold Facts about the „Hot Hand” in Basketball, in. Shafir, Eldar ed.(2004): Preference, Belief, and Similarity: Selected Writings by Amos Tversky, MIT Press, Cambridge - London, 257-267. p.

25. TVersky, Amos - Gilovich, Thomas (1985): The „Hot Hand": Statistical Reality or Cognitiv Illusion, in: Shafir, Eldar ed. (2004): Preference, Belief, and Similarity: Selected Writings by Amos Tversky, MIT Press, Cambridge - London, 269-273. p.

\section{E SZÁMUNKSZERZŐI}

Dr. Barakonyi Károly, egyetemi tanár, Pécsi Tudományegyetem; Dr. Hanyecz Lajos, egyetemi docens, Pécsi Tudományegyetem; Vörös Zsuzsa, Ph. D. hallgató, Pécsi Tudományegyetem; Dr. Agárdi Irma, egyetemi adjunktus, Budapesti Corvinus Egyetem; Dr. Bauer András, egyetemi docens, Budapesti Corvinus Egyetem; Vastag András, egyetemi hallgató, Budapesti Corvinus Egyetem; Péli Gergely, egyetemi hallgató, Budapesti Corvinus Egyetem; Bódis Lívia, egyetemi hallgató, Budapesti Corvinus Egyetem; Honti Katalin, egyetemi hallgató, Budapesti Corvinus Egyetem; Lennert Krisztina, egyetemi hallgató, Budapesti Corvinus Egyetem; Dr. Krisztián Béla, egyetemi docens, Pécsi Tudományegyetem; Rubóczky István, nyugdíjas osztályvezető; Becsky Róbert, főszerkesztő, Vezetéstudomány 